\author{
ANA LJ. VUČIĆEVIĆ ${ }^{1}$ \\ ALEKSANDRA D. RAKIĆ ${ }^{2}$ \\ UNIVERSITY OF KRAGUJEVAC \\ FACULTY OF PHILOLOGY AND ARTS \\ CENTRE FOR LANGUAGE AND LITERATURE RESEARCH
}

\title{
TEXTUAL METADISCOURSE IN ACADEMIC BOOK REVIEWS IN SERBIAN AND ENGLISH
}

\begin{abstract}
This paper examines the forms and patterns of use of the markers of textual metadiscourse in the academic book reviews from the fields of humanities (linguistics and literature) and social sciences (sociology, history, and ethnography) in both Serbian and English languages. The principal aim of our research was to attempt to establish a potential variation in the use of these markers with regard to the parameters of the type of markers, discipline, and language in which the reviews were written. The qualitative-quantitative analysis was carried out according to the model provided by Blagojević (2008). As for the first parameter, the comparison showed the predominance of logical textual connectives in comparison to both other textual connectives and markers of discourse actions/references to discourse across disciplines and languages. When it comes to the parameter of discipline, linguistics, literature and sociology reviews contained the greatest number of markers. Regarding the language criterion, cumulatively speaking, more markers were observed in the reviews in Serbian than in the reviews in English. However, the difference was rather subtle and it pointed to similarities rather than disparities in the use of these markers.
\end{abstract}

\footnotetext{
ana.vucicevic@filum.kg.ac.rs

aleksandra.rakic@filum.kg.ac.rs

This paper was supported by the project grant 178014 from the Ministry of Education, Science and Technological Development of the Republic of Serbia. A version of this paper was presented at the 11th annual conference Contemporary Studies in Language and Literature (the 30th of March, 2019, Kragujevac)

This paper was submitted on May $19^{\text {th }}, 2020$ and accepted for publication at the meeting of the Editorial Board held on September $25^{\text {th }}, 2020$.
} 
KEYWORDS: academic discourse; academic book reviews; textual metadiscourse; disciplines; Serbian; English.

\section{INTRODUCTION}

Academic discourse, be it spoken or written, is produced and perceived among members of the academic discourse community (Blagojević, 2008, p. 22). This implies that there are certain expectations with regard to the goals of academic communication and manners in which its forms are rhetorically shaped to achieve these goals. Namely, an instance of academic speech or writing is aimed at not only presenting research results or professional attitudes, but also at persuading the projected audience into the validity of conveyed ideas, mostly by means of linguistic devices (Hyland 2008 , p. 4; 2009, p. 13). Precisely this social, audience-oriented dimension of academic discourse and its linguistic and rhetorical units is emphasised through the concept of 'metadiscourse'.

The notion itself was redefined numerous times. Ädel (2006, p. 2) points out that metadiscourse enables the writer to guide his or her reader in relation to the anticipated reaction of the reader. Similarly, metadiscourse elements lead the readers through "structure and organization [of a text], [...] the writing process itself or [writer's] opinions and beliefs concerning its content" (Herriman, 2014, p. 1). Similar observations were made for the spoken modality as well (Ädel, 2010; Correia et al., 2015; Zhang et al., 2017). What all have in common is the usual division of metadiscourse elements based on their function. As Dafouz-Milne (2008, p. 97) put it, most authors treat metadiscourse as 'textual' or 'interpersonal', the former referring to the organisation of a text and its coherence, and the latter to the writer's attitudes to a text.

When it comes to the analysis of metadiscourse markers in academic genres, most studies focused on research genres, and in particular on research articles (Mauranen, 1993; Dahl, 2004; Toumi, 2009; $\mathrm{CaO}$ and $\mathrm{Hu}, 2014$ ) or master and doctoral theses (Hyland, 2004; Lin, 2005; Lee and Casal, 2014), predominantly from the perspective of language or disciplinary-conditioned patterns of use of metadiscourse. However, recently a broader scope of analysis in terms of genre has been suggested. Namely, according to some authors, when it comes to other research genres of academic discourse $^{3}$, book reviews, even though important in terms of critical, 
evaluative, and, above all, expert opinion conveyed to academic audiences, are neglected to a certain point in general research (Araújo 1996, p. 17; Motta-Roth 1998, p. 31; Hyland 2009, p. 89).

Having in mind the orientation of a review toward professional audiences and, therefore, the importance of the linguistic elements that aid effective formulation and structuring of evaluation, in this paper we qualitatively and quantitatively examine the markers of textual metadiscourse in the academic reviews of books from the fields of humanities (linguistics and literature) and social sciences (sociology, history, and ethnography) in both Serbian and English languages. Our principal hypotheses are related to the language-specific and disciplinary differences among the two subsets of the corpus. We first of all assume that we may find more types of textual metadiscourse markers in the reviews in English. Also, considering the nature of the disciplines, it may be the case that the reviewers of books from the field of humanities generally use more units of textual metadiscourse and that even when comparing the same disciplines, it is possible to find certain differences conditioned by the language the reviewers use. In accordance with these points, the aims of the study are: 1) to explore the forms the reviewers writing in different languages use in order to organise their texts, 2) to determine potential differences in the use of textual metadiscourse taking into account the types of elements of textual metadiscourse, the nature of discipline-specific rhetorical shaping of a text and the language in which the reviews are written. The results might be significant in terms of, to our knowledge, relatively limited amount of data on similar research of this particular genre (Junqueira and Cortes, 2014; Bal-Gezegin, 2016) and the absence of available information on some similar analysis for the Serbian-English language pair. Moreover, this comparison may be of interest to those intending to enhance the practice of writing reviews in the languages encompassed by the study.

In the following sections we will provide a brief overview of the studies of textual metadiscourse, elaborate on the research methodology, and present and interpret the results with respect to the goals of the study.

3 Hyland proposed a division of academic discourses into research, instructional, student and popular. Book reviews are considered to be research-oriented (Hyland 2009, p. 89). However, book reviews have also been recently classified as review genres (Hyland and Diani, 2009, p. 2; Zou and Hyland, 2020). 


\section{TEXTUAL METADISCOURSE IN A NUTSHELL}

Markers of (textual) metadiscourse have been labelled and classified in different manners depending on the perspective of respective researchers. Among numerous studies, we will single out the ones that offer classifications that are reckoned as particularly influential and can, therefore, be most frequently found in the literature on the topic.

To begin with, the classification offered by Vande Kopple (1985, pp. 83-84) includes: 1) text connectives conveying logical/temporal relationship and performing the functions of sequencing, connecting and reminding, 2) code glosses serving the purpose of clarification, 3) illocution markers announcing the discursive action the author will perform and 4) narrators informing the reader of the source of information. Furthermore, Crismore et al. (1993, p. 47) proposed the model, somewhat similar in terms of function of markers, but with slightly altered terms, encompassing both textual (logical connectives, sequencers, reminders, topicalisers) and interpretive markers (code glosses, illocution markers, announcements). Similarly, Mauranen (1993, pp. 9-10) distinguished between connectors (indicating relationships between different propositions in the text), reviews (referring to the earlier sections of the text), previews (referring to the later sections of the text), and action markers (indicating discourse actions the author performs).

On the other hand, some authors do not use the label 'textual' but establish their own terms. ${ }^{4}$ Ädel defines categories of impersonal metadiscourse such as phorics (pointing to the preceding/following portions of the text), references to the text/code (referring to the explicit level of the text or to some particular expressions in the text), code glosses (facilitating interpretation), and discourse labels (indicating discourse acts) (Ädel, 2006, p. 101; 108; 113; 115). Hyland posits the model of the so-called interactive metadiscourse made up of transitions (indicating connections between stretches of discourse), frame markers (organising the discourse), endophorics (referring to some additional parts of the text), evidentials (provid-

4 The only explicit reference to the label 'textual' was found in Crismore et al. (1993), whereas other previously mentioned authors explain the function of textual metadiscourse either through the prism of textual organisation (Mauranen, 1993) or in relation to the opposition to the markers of validity, attitude and commentary (Vande Kopple, 1985) . 
ing sources), and code glosses (providing explanations and clarifications) (Hyland 2005, pp. 50-52).

When it comes to the research on textual metadiscourse conducted by Serbian authors, it seems that they mostly relied on some of the (aforementioned) foreign classifications for corpora either in Serbian or in some foreign language (compare Piršl, 2009; Koprivica Lelićanin, 2014; Bogdanović, 2017; Figar, 2018; Đorđević and Vesić Pavlović, 2020). To the best of our knowledge, only Blagojević (2008; 2012; 2012a) and Blagojević and Vukić (2012) provided the model of (textual) metadiscourse adapted for contrastive research for the Serbian-English language pair.

\section{RESEARCH PROCEDURE}

\section{RESEARCH METHODOLOGY}

As we stated earlier, markers of textual metadiscourse generally enable and improve the organisation of the information presented in texts. They do not contribute to, nor are part of the propositional content, but are rather used as links between individual propositions "so that they form a cohesive and coherent text" (Vande Kopple, 1985, p. 87). Hyland (1998, p. 442) also observes that these markers show that the writer is aware of his or her reader and wants to both facilitate and direct reader's interpretation. In this sense, textual markers may be very significant with regard to the principal communicative purpose of a book review in academic communication. As is known, book reviews convey professional evaluation of academic books and are thus used to disseminate knowledge, help academics narrow the choice of relevant bibliographic resources and keep abreast of new findings in the field (Hyland and Diani, 2009, p. 2; Junquiera and Cortes, 2014, p. 88). Therefore, textual markers might contribute to a more effective presentation of evaluation that, in return, may influence academic readers.

All elements of textual metadiscourse are classified according to the model provided by Blagojević (2008, p. 95; 2012, p. 93; 2012a, p. 81) and Blagojević and Vukić (2012). Even though it mostly relies on a single source (Vande Kopple, 1985), we opted for this particular classification because it takes into account the specificities of 
contrasting corpora in Serbian and English languages. ${ }^{5}$ The very classification suggests a division into markers of textual connection and markers that signify discourse actions and authorial references to discourse. Markers of textual connection, as their name suggests, link parts of a text, thus contributing to its coherence. These include markers conveying logical relations among propositions and markers with spatio-temporal meaning, the meaning of sequencing, markers with roles of reminding, of reformulating of the previously stated, of introducing propositional content and of emphasising topic. On the other hand, there is a separate and less numerous group of markers denoting both discourse actions the author "performs" and rhetorical segments of discourse the author refers to in the text itself.

Furthermore, the obtained data are quantitatively presented (in percentages) and analysed in terms of distribution according to the type of textual markers, scientific discipline and language in which the reviews are written.

\section{RESEARCH CORPUS}

Our corpus consists of two hundred book reviews ${ }^{6}$ published online in eminent journals ${ }^{7}$ from the fields of humanities (linguistics and literature) and social sciences (sociology, history and ethnography) in both Serbian and English languages. A quantitative distribution of units of the corpus per disciplines and languages is balanced, namely, there are twenty reviews per each discipline and one hundred reviews per language. The balance is also kept in terms of the average length of the compared reviews. As the number of the disciplines is odd and the length of the reviews differs in these two fields, with humanities reviews sometimes exceeding five pages and social sciences reviews not exceeding three pages, the reviews from different fields are not compared. Direct quotations from the reviewed books are not taken into account, as these only serve the reviewers to illustrate and corroborate the evaluations presented in the reviews.

\footnotetext{
The author made significant alterations with regard to categories and terms (see Blagojević, 2008, pp. 90-95).

6 The list of the analysed material is provided in the section Sources.

7 Due to the unavailability of journal sources, ethnography reviews in English were taken from the official website of the particular academic institution.
} 


\section{CORPUS ANALYSIS}

We converted the source texts into Word format and subsequently removed both direct and indirect quotations, footnotes and references from the texts. In order to identify potential markers of textual metadiscourse, we conducted the contextually-dependent corpus analysis manually and independently. Following the initial results check and balancing, we tested and confirmed both the use of markers in contexts and their frequency by means of concordance option in the specialised software Sketch Engine (Kilgarriff et al., 2018). ${ }^{8}$ Subsequently, we obtained the list of markers and classified it according to Blagojević (2008).

In the reviews in both Serbian and English similar elements were identified: markers of textual connection or connectives and markers denoting discourse actions/elements of discourse. Following the model used in the research, connective markers were grouped into markers conveying logical relations among propositions (equality, extension, explanation, cause and effect, opposition, concession, conclusion and comparison) and spatio-temporal markers, as well as sequencing, reminding, leading-in, topicalising and reformulating markers. The analysis of the corpus is presented in the language sections. All markers are illustrated with one authentic example from the corpus. ${ }^{9}$ The qualitative data with accompanying statistical values (percentages) are presented in the tables below.

\section{TEXTUAL CONNECTIVES}

Textual connectives conveying logical relations of:

- equality:

S: dakle, takođe, isto, istovremeno, ujedno, opet, na sličan način, u skladu $\operatorname{satim}(e)$.

8 Nevertheless, we observed some ambiguous instances, predominantly in the sections dedicated to the summary of content. The writer simultaneously presented the content of the book under review and gave his/her own interpretation.

9 All of the examples were coded consistently throughout the analysis: abbreviations for language, discipline and numeral were provided respectively. 
Ona svedoči o sukobu, reklo bi se „doslednih” levičara (komunista) i onih levičara (komunista) [...]. Ukazuje, takođe $e^{10}$, na problematičnost neutemeljenih i nategnutih istorijskih ideologija, analogija i „vertikala". (SH12, p. 203)

E: likewise, at the same time, simultaneously, similarly, so, in line with.

[...] Frazier emphasizes the intentionality of Vietnamese women through their active consideration of how collaborations with 'Western' women could further their own anti-war agendas. Simultaneously, Frazier examines how these interactions created a space for American women to simultaneously condemn the war effort and reconsider their own ideas about femininity and womanhood. (EH17, p. 915)

- extension:

S: štaviše, inače, uzgred, pored ovoga/toga, pored/između ostalog, osim toga, pri tom(e)/pritom, uz to, s(a) druge strane, na drugoj strani.

Последње поглавље [...] ठави се стицањем неопходних знања и могућности за напредак у Азероту. Пореg йоїа, ауторка скреће пажњу на значај романтичарског наслеђа у поимању последица глобалне индустријализације [...]. (SE5, р. 442)

$\mathrm{E}$ : and, moreover, what is more, further, furthermore, also, in addition, additionally, more to the point, apart from, more than that.

Much like the "revolutionary" ideal that charges through the eras of Lee's analysis, moreover, it is a continuum that cannot be essentialized or made universal, even though the contemporary situation creates a paradox of "authenticity," [...]. (ELit1, p. 676)

- explanation:

S: zapravo, naime, na primer (npr. $)^{11}$, to jest (tj.), odnosno, tako, na ovaj/ taj način, u tom smislu/pogledu/ključu, u suštini, u stvari.

Аутор покушава да одреди основне карактеристике биополитичког стања у коме се развија феномен избеглиштва, $\bar{u}$. да дефинише нешто што би се могло назвати биополитичким диспозитивом [...]. (SE4, p. 591)

$\mathrm{E}:$ in this/that sense, in this respect, in this regard/view, under that/the same light, for example, for instance, in fact, in particular, that is, namely, in this context, thus, along these lines, above all, i.e.

10 In both languages markers appear both intra- and inter-sententially (most frequently in initial, but also in medial and final sentential position).

11 The same meaning conveys the lexeme tipa (SLing13). 
By this, Phillips and Milner aim to understand how these phenomena both build and destroy communities: [...]. In this sense, this book is a welcome departure from the 'good or bad' binary often dominating popular media coverage and a great deal of academic work on digital and social media and internet studies. (EE18)

- cause and effect:

S: jer, zato, (upravo) stoga, zbog toga, otud(a), shodno/saglasno tome.

Приказана студија [...] читаоцу нуди обиље емпиријских података и теоријских разматрања. Cūoīa ће она засигурно бити изузетно корисна референца за будуће радове из области фонетике и фонологије српског језика. (SLing2, p. 322)

$\mathrm{E}$ : for, thus, accordingly, consequently, for this or these reasons, therefore, as a result, so.

[...] the poetic work of post-romantic Afro-Atlantics is emblematic of a non-recuperative experience of literature and truth. Consequently, the kind of singular universalism heralded by relation and actualized by lieux communs signifies a recount of Romantic utopianism inscribed into the force of an experience that is life-affirming instead of death-bound, [...]. (ELit4, p. 685)

- opposition:

$\mathrm{S}:$ ali, no, međutim, naprotiv, nasuprot tome $e^{12}$, pak, s(a) jedne strane s(a) druge strane.

Ova poglavlja sadrže i konkretne mere finansijske i ekonomske politike [...]. Međutim, uzevši u obzir kratko, ali burno Varufakisovo iskustvo ministra finansija u vladi A. Ciprasa, očigledno je sa kakvim će se političkim otporom suočavati bilo kakav drugačiji makroekonomski kurs. (SS4, p. 530)

$\mathrm{E}$ : however, but, instead, (on the) contrary, by/in contrast, on the one hand, on the other hand.

The claim is that the 'generative process is optimal', based on 'efficient computation' (71), and that 'this newly emerged computational system for thought ... is perfect, in so far as SMT is correct' (80). However, B\&C give no definition of 'optimal' or 'efficient' or 'perfect'. (ELing1, p. 993)

- concession:

S: ipak, uostalom.

12 Instead of the anaphorical pronoun to the substantive syntagm is used (nasuprot ovim pogledima (SH17)). 
Osobito je zadovoljstvo, zahvaljujući izdavačkoj kući clio, prikazati knjigu Manuela Kastelsa Moć komunikacija [...]. Ipak, poseban je izazov jednu ovako obimnu studiju prikazati na samo nekoliko strana teksta. (SS2: 178)

$\mathrm{E}$ : nonetheless, however, yet, rather, nevertheless, notwithstanding, either way, still.

Questions arise about how Harkness operationalized what is arguably a slippery status. [...] Yet it is common knowledge that gangsta rappers exaggerate gang affiliations and connections to criminal activity as a means to boost publicity and record sales [...]. (ES10, pp. 10001001)

- conclusion:

S: dakle, prema tome.

Vrednost knjige, pored obilja podataka, je $\mathrm{u}$ njenom otvoreno političkom karakteru. Dakle, studija se, pored toga što je akademski tekst, može čitati i kao politički pamflet [...]. (SS6, p. 540)

E: so, thus, then, hence, therefore, after all.

[...] even though virtual worlds are not real, they are nevertheless embedded in the "real world". Hence, virtual worlds are places and have "a sense of worldness" which "offer an objective environment"; they "are multi-user in nature" and "continue to exist in some form even as participants log off” (p. 7). (EE8)

\section{Spatio-temporal markers:}

S: najpre, pre svega, na [samom] početku, zatim, potom, dalje ${ }^{13}$, nadalje, kasnije $^{14}$, u nastavku, nakon toga, konačno, najzad, naposletku, napokon, na [samom] kraju, na koncu.

[...] ауторка у закључку рада истиче изузетан значај есејистике Миодрага Павловића за развој српске књижевности, [...]. Пойом следи преглед литературе [...]. (SLit8, p. 294)

$\mathrm{E}$ : finally, then, next, in the end, meanwhile, later.

While the initial decision to seek an OT-based explanation for rightward movement may find some detractors and strike some as rather ad hoc in nature, I would like to make two remarks: [...].[...] In the end,

13 In some examples from our corpus the lexeme dalje is used adjectivally (u daljem tekstu (SLing1, SS7, SS8), u daljem izlaganju (SLing2), u daljem objašnjavanju (SLing19)).

14 This lexeme is also used as an adjective (u kasnijem poglavlju (SLit4)). 
this book's approachability is limited only by the required background in recent generative theory; [...]. (ELing14, p. 227)

\section{Sequencing markers:}

S: prvo, drugo, treće, četvrto.

Значај монографије [...] рекао ठих, вишеструк је: [...] gруіо, један корпусни материјал који је, тематски посматрано, био изван фокуса истраживача - сада се детаљније предочава читаоцима; üpeћe, у оквиру различитих путева истраживања, што их анализа дискурса отвара/нуди, ауторка се одлучује за онај који је веома важан [...]. (SLing15, p. 160)

E: first, firstly, first of all, first and foremost, second, secondly, third, fourth, fifth, lastly, for one, as a starter, to begin on a...note, following this.

So how are all these asymmetries intrinsically linked to quantitative survey research design? [...] Firstly, for quantitative survey research, statistical expertise is needed to calculate correlations. [...] Secondly, quantitative survey research is built on a strong deductive approach. (EE13)

\section{Markers of reminding:}

$\mathrm{S}$ : kao što smo naveli.

Kao što smo naveli Pavić se 1909. godine nastanio u Kaliforniji [...]. (SH7, p. 200)

$\mathrm{E}$ : as explained above, once again, as mentioned earlier.

As mentioned earlier, upon the death of Arafat, Abbas was elected president [...]. (EH14, p. 907)

\section{Lead-in markers:}

S: performative verbs; authorial questions.

Детаљније ћемо се заgржаӣи на саgржају четвртог тома, али ћемо gā̄u и најкраћи ӣриказ осталих. (SLing5, pp. 219-220).

E: performative verbs used solely or in combination with nouns announcing the content to be presented; authorial questions.

The only word of caution that I must include is one already noted in its blurb [...]. (EE2)

Markers of topic: 
S: u vezi sa tim(e) (s tim(e) u vezi).

Међу опсесивним мотивима и темама нарочито се издвајају вода и река [...]. У вези са йиме, пригодна фуснота резимира у свега неколико редова битне студије о симболици воде у роману [...]. (SLit5, p. 283)

E: in terms of, with regard to, on the issue of, as to, for, in view of, as regards, regarding, with respect to, as for.

With regard to the latter aspect, R's work is entirely consistent with Chomsky's suggestion [...]. (ELing11, p. 723)

Markers of reformulation:

S: najšire gledano, uže gledano, u najkraćem, recimo, drugim rečima, tačnije, preciznije, ukratko, tzv.

Ovo je stvaralo plodno tle za albanski iredentizam [...]. Drugim rečima, Gatalović je jasno uvideo povezanost ekonomske nerazvijenosti, inostrane propagande i neprijateljskih tendencija unutar Kosova i Metohije. (SH9, p. 207)

E: in other words, overall, in sum, to sum up, in short, (more) specifically, summing up, stated otherwise, (more) precisely, to put it differently, briefly, put simply, to reiterate, more narrowly, stated another way, or rather, this is to say, long story short.

The proposed analysis relies on the observation that non performative eventives in the simple present cannot have an episodic interpretation due to the PPP. In other words, because the English present is perfective (characterized as 1), a paradox emerges for non-performative eventives. (ELing16, p. 473)

\section{MARKERS OF DISCOURSE ACTIONS AND REFERENCES TO DISCOURSE}

\section{Markers of discourse actions}

S: performative verbs - zaključiti, istaći/isticati, sagledavati, predstavljati, zadržati se, dati prikaz (prikazati)/prikazivati, navesti/navoditi; combination of modals, discourse actions and markers of attitude in active or passive constructions - možemo zaključiti/da zaključimo (može se zaključiti), nastojimo da ukažemo, možemo reći, mogli bismo ispitivati, moguće je da navedemo; nouns denoting discourse actions namera. 
Књига коју йреgсииављамо објављена је крајем 2016. године [...]. (SLing3, p. 323)

E: performative verbs used either solely or in combination with: modals in active, passive or impersonal constructions; hortative modals (let) in active constructions by means of which the writer encourages the reader to perform discourse action with him/her add, say, ask, include, name, address, conclude, propose, outline, close; nouns denoting discourse actions - conclusion.

In conclusion, contrary to B\&C's claims, there is an enormous amount to discover when it comes to language evolution, [...]. (ELing1, p. 996)

Markers of authorial references to discourse

S: nouns referring to (part of) review - (ovaj) prikaz, završna reč, kraj (ovog) prikaza; adverbs sada and ovde and their periphrastic equivalents - na ovom mestu, ovom prilikom.

$\mathrm{Na}$ ovom mestu smo odabrali da se osvrnemo samo na neke aspekte ove studije [...]. (SS1, p. 173)

E: nouns referring to (part of) review; adverb here.

In the final part of this review I would like to address two broader aspects of R's claims [...]. (ELing7, p. 486)

\section{DISCUSSION}

Following the qualitative analysis, the quantitative comparison was performed. Tables 1 and 3 show the number and percentage of textual connectives expressing logical relations among propositions in the academic book reviews in Serbian and English, while Tables 2 and 4 illustrate the number and percentage of the remaining groups of textual connectives and markers of discourse actions/ authorial references to discourse in both languages respectively. 


\begin{tabular}{|c|c|c|c|c|c|c|c|c|c|c|c|c|c|c|c|c|}
\hline \multirow[t]{2}{*}{$\begin{array}{l}\text { DISCIPLINE } \\
\text { (SERBIAN) }\end{array}$} & \multicolumn{2}{|c|}{ 岕 } & \multicolumn{2}{|c|}{$\begin{array}{l}\dot{y} \\
\text { Z } \\
\text { 㐫 }\end{array}$} & \multicolumn{2}{|c|}{ 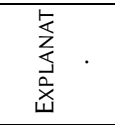 } & \multicolumn{2}{|c|}{ نّ } & \multicolumn{2}{|c|}{$\begin{array}{l}\dot{0} \\
\vdots \\
0 \\
0\end{array}$} & \multicolumn{2}{|c|}{$\begin{array}{l}\dot{\tilde{u}} \\
\tilde{u} \\
\text { ठ }\end{array}$} & \multicolumn{2}{|c|}{$\begin{array}{l}\dot{y} \\
\vec{U} \\
\mathrm{U} \\
0\end{array}$} & \multicolumn{2}{|c|}{$\begin{array}{l}\vec{E} \\
\stackrel{5}{\circ}\end{array}$} \\
\hline & $N$ & $P$ & $N$ & $\mathrm{P}$ & $\mathrm{N}$ & $P$ & $\mathrm{~N}$ & $\mathrm{P}$ & $N$ & $P$ & $\mathrm{~N}$ & $\mathrm{P}$ & $\mathrm{N}$ & $P$ & $\mathrm{~N}$ & $\mathrm{P}$ \\
\hline LINGUISTICS & $a$ & $\stackrel{\stackrel{\sim}{\sim}}{\underset{+}{+}}$ & 아 & సे. & $\stackrel{m}{\exists}$ & 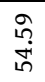 & $F$ & in & 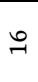 & $\stackrel{n}{\stackrel{n}{r}}$ & $a$ & $\stackrel{\mathscr{n}}{\underset{\sigma}{+}}$ & $a$ & $\stackrel{\stackrel{\sim}{\sim}}{\underset{+}{+}}$ & iे & $\begin{array}{l}\text { นั } \\
\text { ஸे }\end{array}$ \\
\hline LITERATURE & $\stackrel{0}{\sim}$ &  & $\stackrel{2}{\sim}$ & $\begin{array}{l}\underset{7}{7} \\
\infty \\
\end{array}$ & Fे & $\begin{array}{l}\stackrel{n}{\stackrel{n}{+m}} \\
\stackrel{m}{n}\end{array}$ & $\infty$ & ث̊ํํ & iे & $\begin{array}{l}\hat{n} \\
\text { in }\end{array}$ & 욱 & 오․ & $m$ & $\stackrel{m}{i}$ & $\vec{I}$ & $\underset{7}{\stackrel{7}{-}}$ \\
\hline SOCIOLOGY & $\tilde{N}$ & $\vec{n}$ & $\hat{N}$ & n̊. & 요 & $\underset{m}{\stackrel{m}{\infty}}$ & $\stackrel{\infty}{N}$ & n̊ & 8 & 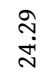 & $\tilde{n}$ & $\vec{m}$ & ન & $\begin{array}{l}\infty \\
\substack{\infty \\
0}\end{array}$ & $\stackrel{\infty}{N}$ & $\begin{array}{l}\text { Ț } \\
\stackrel{\text { pे }}{ }\end{array}$ \\
\hline ETHNOGRAPHY & i) & 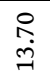 & กิ & ì & 号 & 商 & $\approx$ & $\underset{\infty}{\mathbb{N}}$ & $\stackrel{\llcorner}{N}$ & $\underset{7}{\stackrel{7}{7}}$ & n & $\stackrel{q}{f}$ & n & 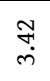 & $\stackrel{7}{I}$ & $\begin{array}{l}\tilde{\delta} \\
\infty \\
\sim \\
\sim\end{array}$ \\
\hline HISTORY & $\approx$ & 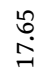 & $\stackrel{2}{\sim}$ & $\begin{array}{l}\stackrel{\circ}{\mathrm{N}} \\
\text { în }\end{array}$ & $\stackrel{\sim}{\sim}$ & $\begin{array}{l}\stackrel{\leftrightarrow}{+} \\
\text { ì }\end{array}$ & 0 & $\stackrel{8}{\circ}$ & i & $\begin{array}{l}\overrightarrow{7} \\
\stackrel{\text { ลे }}{ }\end{array}$ & $\sigma$ & $\begin{array}{l}\infty \\
\infty \\
\stackrel{n}{\infty}\end{array}$ & N & $\stackrel{\text { Si }}{\text { i }}$ & $\stackrel{\infty}{\circ}$ & $\underset{\infty}{\stackrel{9}{1}}$ \\
\hline TOTAL & $\infty$ & $\begin{array}{l}\infty \\
\infty \\
\sigma\end{array}$ & $\stackrel{\ominus}{-}$ & 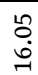 & ర్లి & 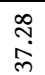 & î & 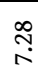 & ஜ̊ & $\begin{array}{l}\text { N } \\
\text { ก } \\
\infty \\
\end{array}$ & in & :ூુ & $\stackrel{m}{m}$ & $\underset{+}{\stackrel{J}{+}}$ & 옹 & - \\
\hline
\end{tabular}

TABLE 1: THE NUMBER (N) AND PERCENTAGE (P) OF TEXTUAL CONNECTIVES CONVEYING LOGICAL RELATIONS IN BOOK REVIEWS IN SERBIAN

\begin{tabular}{|c|c|c|c|c|c|c|c|c|c|c|c|c|c|c|c|c|c|c|}
\hline \multirow[t]{2}{*}{$\begin{array}{l}\text { DISCIPLINE } \\
\text { (SERBIAN) }\end{array}$} & \multicolumn{2}{|c|}{$\begin{array}{l}\dot{U} \\
\dot{U}\end{array}$} & \multicolumn{2}{|c|}{ í } & \multicolumn{2}{|c|}{$\begin{array}{l}\dot{z} \\
\text { 己. } \\
\vec{w} \\
w\end{array}$} & \multicolumn{2}{|c|}{ 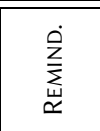 } & \multicolumn{2}{|c|}{$\begin{array}{l}z \\
z \\
\dot{1} \\
\text { 岁 }\end{array}$} & \multicolumn{2}{|c|}{$\frac{\dot{u}}{0}$} & \multicolumn{2}{|c|}{ 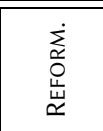 } & \multicolumn{2}{|c|}{ 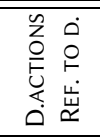 } & \multicolumn{2}{|c|}{ 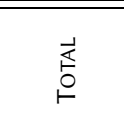 } \\
\hline & $\mathrm{N}$ & $P$ & $\mathrm{~N}$ & $P$ & $\mathrm{~N}$ & $\mathrm{P}$ & $\mathrm{N}$ & $P$ & $\mathrm{~N}$ & $\mathrm{P}$ & $\mathrm{N}$ & $P$ & $\mathrm{~N}$ & $P$ & $N$ & $P$ & $\mathrm{~N}$ & $P$ \\
\hline LINGUISTICS & $\hat{\text { ̀े }}$ & $\begin{array}{l}\text { ồ } \\
\text { fi }\end{array}$ & $\stackrel{\infty}{\circ}$ & $\begin{array}{l}\text { no } \\
\dot{\text { i }}\end{array}$ & $\stackrel{ }{-}$ & $\stackrel{\circ}{\stackrel{9}{m}}$ & $\circ$ & $\stackrel{8}{\circ}$ & $m$ & ח̆ & 0 & $\stackrel{8}{\circ}$ & $\stackrel{2}{\sim}$ & $\underset{+}{\stackrel{+}{*}}$ & จ & नें & 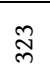 & $\begin{array}{l}\text { oे } \\
\infty \\
\text { iो }\end{array}$ \\
\hline LITERATURE & $\underset{J}{ت}$ & $\stackrel{\vec{n}}{\mathrm{~N}}$ & ల్ & $\underset{\substack{7 \\
\stackrel{7}{0}}}{7}$ & 0 & 8 & 0 & $\stackrel{0}{0}$ & $\sigma$ & 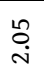 & $\neg$ & हn̊ & $a$ & $\underset{+}{\mathbb{T}}$ & $\infty$ & 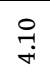 & $\stackrel{\curvearrowleft}{2}$ & ஃ̊ \\
\hline SOCIOLOGY & $\stackrel{\infty}{\underset{H}{N}}$ & $\stackrel{\sqrt[n]{n}}{\text { N }}$ & $\stackrel{m}{m}$ & ก̊. & -1 & ঙั. & 0 & $\stackrel{8}{\circ}$ & $\stackrel{0}{-1}$ & $\underset{\substack{\infty \\
\hdashline}}{0}$ & $\theta$ & Э닥 & $\vec{N}$ & $\stackrel{\sharp}{\breve{b}}$ & $\stackrel{0}{-1}$ & 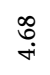 & సै & 离 \\
\hline ETHNOGRAPHY & 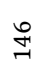 & $\begin{array}{l}\stackrel{n}{m} \\
\text { o. } \\
\end{array}$ & $\approx$ & กู่ & 0 & $\stackrel{8}{\circ}$ & 0 & $\stackrel{8}{\circ}$ & $\wedge$ & $\underset{\sim}{\stackrel{一}{m}}$ & 0 & $\stackrel{0}{\circ}$ & $\approx$ & $\underset{N}{\pi}$ & N & 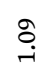 & $\stackrel{\infty}{\sim}$ & $\begin{array}{l}8 \\
\\
\stackrel{0}{\circ}\end{array}$ \\
\hline HISTORY & $\infty$ & 告 & $\stackrel{\circ}{\sim}$ & $\begin{array}{l}\text { oे } \\
\text { فे }\end{array}$ & -1 & ઠ̆ & - & ઠ̆. & $a$ & 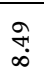 & -1 & $\begin{array}{l}\text { S̆ } \\
\text { S. }\end{array}$ & $r$ & $\stackrel{尺}{\stackrel{一}{m}}$ & 0 & $\begin{array}{l}\stackrel{8}{0} \\
\text { in }\end{array}$ & $\stackrel{\circ}{\circ}$ & స్ \\
\hline TOTAL & $\underset{\infty}{\stackrel{0}{0}}$ & $\stackrel{m}{\stackrel{m}{0}}$ & త্ర & $\underset{\stackrel{\sim}{~}}{\stackrel{\sim}{\sim}}$ & $\approx$ & $\stackrel{r}{\circ}$ & - & ò. & के & $\stackrel{\tilde{m}}{m}$ & $\circ$ & กี้ & $\stackrel{8}{\circ}$ & $\stackrel{\vec{i}}{i}$ & in & 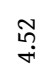 & $\stackrel{\circ}{\circ}$ & - \\
\hline
\end{tabular}

TABLE 2: THE NUMBER (N) AND PERCENTAGE (P) OF THE REMAINING TEXTUAL CONNECTIVES AND MARKERS OF DISCOURSE ACTIONS/REFERENCES TO DISCOURSE IN THE BOOK REVIEWS IN SERBIAN 


\begin{tabular}{|c|c|c|c|c|c|c|c|c|c|c|c|c|c|c|c|c|}
\hline \multirow[t]{2}{*}{$\begin{array}{l}\text { DISCIPLINE } \\
\text { (ENGLISH) }\end{array}$} & \multicolumn{2}{|c|}{ 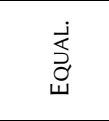 } & \multicolumn{2}{|c|}{ 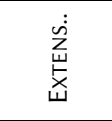 } & \multicolumn{2}{|c|}{ 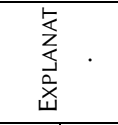 } & \multicolumn{2}{|c|}{ نَّ } & \multicolumn{2}{|c|}{$\begin{array}{l}\dot{0} \\
0 \\
0 \\
0\end{array}$} & \multicolumn{2}{|c|}{$\begin{array}{l}\dot{w} \\
\tilde{u} \\
\underline{z} \\
0 \\
ن\end{array}$} & \multicolumn{2}{|c|}{$\begin{array}{l}\dot{v} \\
\vec{U} \\
\text { ż } \\
\text { U }\end{array}$} & \multicolumn{2}{|c|}{$\begin{array}{l}\overrightarrow{\overleftarrow{E}} \\
\stackrel{\circ}{\vdash}\end{array}$} \\
\hline & $\mathrm{N}$ & $P$ & $\mathrm{~N}$ & $P$ & $\mathrm{~N}$ & $\mathrm{P}$ & $\mathrm{N}$ & $P$ & $\mathrm{~N}$ & $P$ & $\mathrm{~N}$ & $\mathrm{P}$ & $\mathrm{N}$ & $\mathrm{P}$ & $\mathrm{N}$ & $\mathrm{P}$ \\
\hline LINGUISTICS & 욱 & $\begin{array}{l}\infty \\
\stackrel{\infty}{\infty}\end{array}$ & $\stackrel{\circ}{\sim}$ & กี. & $\sigma$ & $\begin{array}{l}\stackrel{8}{0} \\
+ \\
\text { m. }\end{array}$ & $\stackrel{\infty}{\sim}$ & $\stackrel{\infty}{\stackrel{\circ}{\sim}}$ & 6 & $\begin{array}{l}n \\
\stackrel{\sim}{N}\end{array}$ & ने & 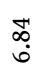 & m & $\vec{m}$ & స్ర & $\begin{array}{l}\stackrel{P}{\text { f }} \\
\text { m }\end{array}$ \\
\hline LITERATURE & $N$ & $\stackrel{\text { f }}{\rightarrow}$ & $\therefore$ & $\begin{array}{l}\stackrel{0}{0} \\
\text { İ }\end{array}$ & $F$ & 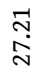 & $\stackrel{0}{-1}$ & $\begin{array}{l}\stackrel{0}{1} \\
\text { ㄱ. }\end{array}$ & $\approx$ & $\begin{array}{l}\sigma \\
\text { ò } \\
\text { - }\end{array}$ & $\stackrel{\pi}{N}$ & $\begin{array}{l}\hat{\alpha} \\
\hat{n}\end{array}$ & $\bar{N}$ & 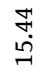 & $\underset{\sim}{\stackrel{J}{\prime}}$ & $\begin{array}{l}\hat{0} \\
\text { वे }\end{array}$ \\
\hline SOCIOLOGY & $n$ & $\begin{array}{l}\stackrel{0}{h} \\
\text { in } \\
\end{array}$ & $\stackrel{\sim}{\Omega}$ & 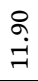 & $\hat{N}$ & 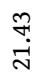 & 0 & $\stackrel{?}{\stackrel{\circ}{+}}$ & m & $\begin{array}{l}\hat{n} \\
\text { in } \\
\text { in }\end{array}$ & $\tilde{n}$ & 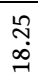 & ำ & స్ & $\underset{్}{\sim}$ & $\begin{array}{l}0 \\
\stackrel{0}{0} \\
\stackrel{0}{0}\end{array}$ \\
\hline ETHNOGRAPHY & $\sigma$ & $\begin{array}{l}\text { S } \\
\text { ì }\end{array}$ & $\stackrel{1}{1}$ & $\stackrel{?}{\stackrel{2}{=}}$ & $\grave{N}$ & $\begin{array}{l}\infty \\
\infty \\
\stackrel{\sim}{\rightarrow}\end{array}$ & 0 & $\underset{+}{F}$ & $\stackrel{m}{m}$ & 离 & $F$ & 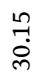 & $n$ & $\stackrel{n}{n}$ & ల్లె & $\begin{array}{l}\overrightarrow{0} \\
\infty \\
\stackrel{0}{\sim}\end{array}$ \\
\hline HISTORY & $\sigma$ & $\underset{+}{\stackrel{8}{+}}$ & $\stackrel{2}{2}$ & $\stackrel{\mathbb{N}}{\stackrel{7}{7}}$ & 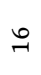 & 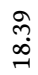 & $\sigma$ & 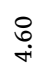 & $\vec{N}$ & 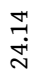 & ก & సે & in & $\stackrel{n}{\stackrel{n}{n}}$ & $\widehat{\infty}$ & $\underset{ }{\stackrel{N}{7}}$ \\
\hline TOTAL & $\hat{N}$ & $\stackrel{\infty}{\substack{n \\
n}}$ & $\infty$ & $\stackrel{\overbrace{}}{ت}$ & ণิ & 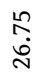 & in & రై & $\stackrel{\circ}{\infty}$ & 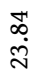 & సิ & : & $\stackrel{\infty}{\wedge}$ & $\underset{\tilde{m}}{\stackrel{0}{0}}$ & $\stackrel{n}{\wedge}$ & - \\
\hline
\end{tabular}

TABLE 3: THE NUMBER (N) AND PERCENTAGE (P) OF TEXTUAL CONNECTIVES CONVEYING LOGICAL RELATIONS IN BOOK REVIEWS IN ENGLISH

\begin{tabular}{|c|c|c|c|c|c|c|c|c|c|c|c|c|c|c|c|c|c|c|}
\hline \multirow[t]{2}{*}{$\begin{array}{c}\text { DISCIPLINE } \\
\text { (ENGLISH) }\end{array}$} & \multicolumn{2}{|c|}{ نे } & \multicolumn{2}{|c|}{$\bar{s}$} & \multicolumn{2}{|c|}{ 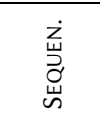 } & \multicolumn{2}{|c|}{ 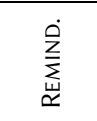 } & \multicolumn{2}{|c|}{ 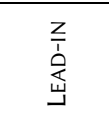 } & \multicolumn{2}{|c|}{$\begin{array}{l}\frac{\dot{U}}{0} \\
\stackrel{0}{\circ}\end{array}$} & \multicolumn{2}{|c|}{ 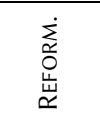 } & \multicolumn{2}{|c|}{ 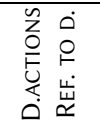 } & \multicolumn{2}{|c|}{$\vec{క}$} \\
\hline & $\mathrm{N}$ & $\mathrm{P}$ & $\mathrm{N}$ & $\mathrm{P}$ & $\mathrm{N}$ & $\mathrm{P}$ & $\mathrm{N}$ & $\mathrm{P}$ & $\mathrm{N}$ & $\mathrm{P}$ & $\mathrm{N}$ & $\mathrm{P}$ & $\mathrm{N}$ & $P$ & $\mathrm{~N}$ & $\mathrm{P}$ & $\mathrm{N}$ & $\mathrm{P}$ \\
\hline LINGUISTICS & స్ర & $\begin{array}{l}: \\
:\end{array}$ & $\stackrel{\infty}{\sim}$ & $\stackrel{\vec{n}}{+}$ & $\mathcal{7}$ & $\begin{array}{l}\overrightarrow{0} \\
\dot{m}\end{array}$ & $r$ & $\stackrel{\stackrel{\sim}{N}}{0}$ & in & $\begin{array}{r}\tilde{m} \\
\tilde{m}\end{array}$ & $\pi$ & $\begin{array}{l}\stackrel{n}{n} \\
\text { r. }\end{array}$ & $\stackrel{\infty}{\sim}$ & $\stackrel{\vec{r}}{\vec{f}}$ & N & $\begin{array}{l}\vec{n} \\
\text { nू }\end{array}$ & ळे & $\begin{array}{l}\infty \\
\infty \\
\stackrel{m}{m}\end{array}$ \\
\hline LITERATURE & $\underset{J}{J}$ & $\underset{\hat{\sigma}}{\delta}$ & $\sigma$ & 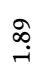 & $N$ & ó & - & f̊ & $\stackrel{\llcorner}{N}$ & શે & n & ঙ্লি & $\approx$ &  & 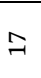 & $\begin{array}{l}\tilde{O} \\
\infty \\
\infty\end{array}$ & సี & $\begin{array}{l}\text { Oे. } \\
\stackrel{\sim}{\circ}\end{array}$ \\
\hline SOCIOLOGY &  & ণึ. & in & 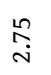 & $r$ & $\stackrel{\text { ণ }}{\text { i }}$ & 0 & $\stackrel{8}{0}$ & m & 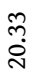 & $\pi$ & ঙ্ণ & in & 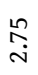 & -1 & $\begin{array}{l}\text { 莒 } \\
0\end{array}$ & $\underset{\sim}{N}$ & 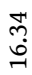 \\
\hline $\begin{array}{c}\text { ETHNOGRAP } \\
\mathrm{HY}\end{array}$ & $\stackrel{\text { లొ }}{\rightarrow}$ & $\underset{\substack{8 \\
\infty \\
\infty}}{0}$ & 우 & $\begin{array}{l}8 \\
\dot{0}\end{array}$ & ने & $\begin{array}{l}\text { ஜn. } \\
\text { nุ. }\end{array}$ & 0 & $\begin{array}{l}\circ \\
\circ\end{array}$ & 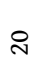 & 8 & - & 䓍 & $\infty$ & $\stackrel{\text { }}{\circ}$ & 0 & $\underset{\dot{m}}{\stackrel{一}{ }}$ & ঃ & $\stackrel{\swarrow}{\approx}$ \\
\hline HISTORY & $\hat{\infty}$ & 帛 & 0 & $\begin{array}{l}\stackrel{\circ}{+} \\
\stackrel{+}{2}\end{array}$ & $\wedge$ & $\underset{\hat{i}}{\stackrel{9}{i n}}$ & - & 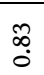 & 0 & $\underset{+}{\stackrel{\circ}{+}}$ & - & 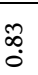 & n & શ્ & 0 & $\stackrel{\text { \&̊ }}{+}$ & $\overrightarrow{\mathfrak{J}}$ & $\begin{array}{l}\stackrel{\circ}{\circ} \\
\stackrel{0}{0}\end{array}$ \\
\hline TOTAL & 品 & 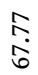 & F & $\begin{array}{l}\stackrel{\infty}{\infty} \\
\stackrel{\text { m}}{2}\end{array}$ & $\exists$ & $\stackrel{n}{n}$ & $m$ & సু & 욕 & în & $\hat{N}$ & $\underset{\text { N }}{\text { N }}$ & in & $\underset{+}{\text { ఫे }}$ & in & $\stackrel{\hat{\leftarrow}}{+}$ & $\underset{\exists}{\Xi}$ & $\gamma$ \\
\hline
\end{tabular}

TABLE 4: THE NUMBER (N) AND PERCENTAGE (P) OF THE REMAINING TEXTUAL CONNECTIVES AND MARKERS OF DISCOURSE ACTIONS/REFERENCES TO DISCOURSE IN THE BOOK REVIEWS IN ENGLISH

As is stated in the introductory parts of this paper, the focal point of the analysis is the distribution of markers of textual meta- 
discourse in relation to the parameters of the type of textual markers, scientific discipline and language in which the reviews are written.

In terms of the type of markers, markers conveying logical relations are more numerous than both other types of textual connectives and markers of discourse actions/references to discourse across all disciplines and in both languages. Namely, as Table 2 shows, out of the total number of textual markers in the reviews in Serbian (1150), almost four fifths (70.43\%) were markers of logical relations. Similarly, Table 4 illustrates that, in the reviews in English, in comparison to the total number (1114), logical markers remained the predominant group with a share more than three and a half times greater than other types (67.77\%).

Furthermore, when it comes to a particular type of logical markers, as Tables 1 and 3 show, the reviews across all disciplines and in both languages share the greatest number of markers in function of explanation (37.28\% in the reviews in Serbian and $26.75 \%$ in the reviews in English), followed by markers of opposition (18.52\%) and extension (16.05\%) in the corpus in Serbian, and opposition (23.84\%) and concession (17.09\%) in the corpus in English. On the other hand, the lowest numbers in the reviews in Serbian are observed for markers of conclusion (4.44\%) and concession (6.54\%), and in the reviews in English for equality (3.58\%) and cause and effect (6.62\%).

Regarding the remaining types of textual connectives, Tables 2 and 4 display similar numbers in both reviews in Serbian (288) and English (307). Moreover, as can be seen in Table 2, spatio-temporal (14.26\%) and reformulation (5.74\%) markers are most numerous in the reviews in Serbian, whereas Table 4 indicates the greatest number of lead-in markers (12.57\%) in the reviews in English. The common point for all disciplines and both languages is the low number of reminding markers $(0.09 \%$ in the reviews in Serbian and $0.27 \%$ in the reviews in English).

As for markers of discourse actions and authorial references to discourse, as Tables 2 and 4 show, the numbers are approximately the same across languages $(4.52 \%$ in the reviews in Serbian and $4.67 \%$ in the reviews in English), with the greatest values observed in linguistics book reviews (6.19\% and $5.51 \%$ in the respective languages).

The predominance of logical markers implies that authors writing in both Serbian and English show the same tendency to link dis- 
course units on the basis of the logical relation more than to organise the presentation of the propositional content. On the one hand, this facilitates the interpretation of facts. However, it may make it more difficult to the reader to follow the flow of the text, that is, to notice a change of topic, prominence of ideas, their ordering according to that prominence, ideational connection between larger units of text (paragraphs or sections) and so on. This may be due to the nature of the genre, namely, book reviews are usually short and when it comes to our corpus, are mostly informative ${ }^{15}$. It follows that, in such reviews, there are not many rhetorical moves due to brevity, desired conciseness and focus on information. The authors emphasise the importance of a valid interpretation of facts from the reviewed book and their interrelations more than the evaluative aspect. More to the point, we may even state that this is the reason why logical markers of explanation dominate in both languages - the authors want to ensure the appropriate interpretation of facts from the book.

With regard to other types of textual connectives and markers of discourse actions/references to discourse, the reviewers in both languages show somewhat similar tendencies, with only subtle differences observed in the use of the specific subtype of markers.

As for the disciplinary parameter, the highest number of all textual markers in the reviews in Serbian is observed in the reviews dealing with sociological (29.74\%) and linguistic (28.09\%) issues (Table 2). On the other hand, the numbers for the corpus in English shown in Table 4 illustrate the highest percentage of all textual markers in linguistics (35.82\%) and literature (19.03\%) reviews. The lowest number is detected in history reviews $(9,22 \%$ in the reviews in Serbian and $10.86 \%$ in the reviews in English) and, as opposed to the corpus in Serbian, in sociology reviews in English (16.34\%). Ethnography reviews also contain some of the lowest values in both Serbian (16\%) and English (17.95\%) corpora.

As can be noticed, linguistics and literature reviewers tend to use textual markers to a greater extent. Even though the two are generally akin, linguistics as a discipline tends to be more exact-like, presenting facts almost in the fashion of natural sciences. On the other hand, literature is scientific as well, but at the same time it

15 Book reviews are considered to be informative/descriptive and/or evaluative/ critical. The former predominantly summarise the content of the reviewed material, whereas the latter mostly convey the reviewer's critical assessment (Motta-Roth, 1995; Motta-Roth, 1996; Gea Valor, 2000, p. 10; Šandová, 2018). 
seems to be more artistic and therefore subjective to an extent. The nature of the disciplines is reflected in the reviews as well. In our corpus, linguistics reviews predominantly enumerate and, in an exact-like manner, explain linguistic mechanisms the reviewed books deal with. Literature reviews cast light on both facts and evaluation. Therefore, having in mind both epistemological differences and similarities and high numbers of textual markers, it is perhaps possible to infer that these values may be ascribed to formal education professional philologists go through. Namely, we assume that they are trained to be aware of their potential audience as well as of diverse language resources to rely on in communication. As for the reviews from the field of social sciences, a relatively low number of textual markers in history reviews may be conditioned by the tendency to chronicle and enumerate historical events and other various data.

Lastly, from a contrastive perspective, it is possible to say that, on a general level, there are more diverse textual markers in the reviews in English and also quantitatively more markers of textual metadiscourse in the reviews in Serbian, though the difference is slight.

These data provide evidence that the writers of book reviews from these two academic communities follow certain similar patterns of textual connection and discourse organisation. First of all, when it comes to the type of textual markers, it has been observed that the reviewers in both Serbian and English use the same types across all categories in the applied model. Also, due to the nature of the genre, textual connectives conveying logical relations are most numerous in both languages, with precedence of those with explanatory function. Presumably, the aim is to convey facts and evaluations and elaborate on them. More to the point, the reviewers in both languages use a practically identical number of the remaining types of textual connectives and markers of discourse actions/authorial references to discourse, which further implies they similarly pay attention to different manners of organisation of the presented propositional content. Secondly, the epistemology of the discipline may influence the need of the author to lead the reader through the discourse of the book review. Namely, chronological, factual information is less liable to multiple perspectives, whereas dynamic issues certain disciplines tackle require that the author should use different means to convey that dynamism to the reader. 
In conclusion, we may state that even though the writers belong to different academic communities in the sense of potentially diverse practices of academic writing, it seems that, when it comes to this academic genre and the use of the markers of textual metadiscourse, there are no significant points of divergence.

CONCLUSION In this paper the qualitative-quantitative analysis of the markers of textual metadiscourse in Serbian and English book reviews was performed. The comparison was based on three parameters: the type of markers, discipline and language of the review.

Our initial assumptions were only partly confirmed. Namely, we hypothesised about the differences in the use of textual markers in terms of their type as well as across disciplines and languages in question. However, the results showed only a subtle variation when it comes to these parameters. As we have already stated, all types of markers from the model were used in both languages. Textual connectives conveying logical relations are used to a great extent across disciplines and in both languages. In comparison to other disciplines, the number of textual markers is significantly greater in linguistics reviews in both languages, literature reviews in English as well as in sociology reviews in Serbian, which implies that not only the reviews from the field of humanities, but also the reviews from certain social sciences may contain a greater number of textual metadiscourse markers. Generally speaking, the number of all markers is relatively greater in the reviews in Serbian. However, it is possible to say that the number does not indicate any significant difference.

In the light of the previously stated, we hope that the results of our research may be useful to reviewers writing within different disciplines. The forms diversified according to their meaning, sentential positioning and the manner textual markers aid organisation of a text can help reviewers more explicitly and efficiently convey their ideas to expert audiences. Moreover, we suggest more thorough research of this genre in the future in terms of a greater number of parameters. For instance, it is possible to include subgenre differentiation in terms of informative-evaluative distinction in order to obtain a more detailed account of the patterns of use of textual metadiscourse in this academic genre, and, consequently, a kind of instruction for reviewers to adequately profile their reviews into a balanced blend of information and evaluation. 
REFERENCES Ädel, A. (2006). Metadiscourse in L1 and L2 English. Amsterdam/Philadelphia: John Benjamins.

Ädel, A. (2010). Just to Give You Kind of a Map of Where We Are Going: A Taxonomy of Metadiscourse in Spoken and Written Academic English. Nordic Journal of English Studies, 9 (2), 69-97.

Araújo, A. D. (1996). Lexical signalling: A study of unspecific nouns in book reviews (the manuscript of defended doctoral thesis). UFSC, Florianópolis.

Bal-Gezegin, B. (2016). A Corpus-based Investigation of Metadiscourse in Academic Book Reviews. Procedia - Social and Behavioral Sciences, 232, 713718.

Blagojević, S. (2008). Metadiskurs u akademskom diskursu. Niš: Filozofski fakultet.

Blagojević, S. (2012). O engleskom i srpskom akademskom diskursu. Niš: Filozofski fakultet.

Blagojević, S. (2012a). How to Help a Reader Trough an Academic Article? Signalling Devices in Research Articles Written by English and Serbian Academics. Facta Universitatis: Series Linguistics and Literature. 10 (2), 79-87.

Blagojević, S. and Vukić, M. (2012). Tekstualni konektori za izražavanje logičkih odnosa u srpskom i engleskom akademskom diskursu. In: M. Kovačević (Ed.), Zbornik radova sa VI međunarodnog naučnog skupa održanog na Filološko-umetničkom fakultetu u Kragujevcu: Strukturne karakteristike srpskog jezika (477-488). Kragujevac: Filološko-umetnički fakultet.

Bogdanović, V. (2017). Žanr i metadiskurs u odabranim udžbenicima engleskog jezika struke. Novi Sad: Filozofski fakultet.

Cao, F. and Hu, G. (2014). Interactive metadiscourse in research articles: A comparative study of paradigmatic and disciplinary influences. Journal of Pragmatics, 66, 15-31.

Correia, R. et al. (2015). Lexical Level Distribution of Metadiscourse in Spoken Language. In: Proceedings of the EMNLP 2015 Workshop on Linking Models of Lexical, Sentential and Discourse-level Semantics (70-75). Lisboa: Association for Computational Linguistics.

Crismore, A. et al. (1993). Metadiscourse in Persuasive Writing: A study of Texts Written by American and Finnish University Students. Written Comunication, 10 (1), 39-71.

Dafouz-Milne, E. (2008). The pragmatic role of textual and interpersonal metadiscourse markers in the construction and attainment of persuasion: A cross-linguistic study of newspaper discourse. Journal of Pragmatics, 40 (1), 95-113.

Dahl, T. (2004). Textual metadiscourse in research articles: a marker of national culture or of academic discipline?. Journal of Pragmatics, 36 (10), 1807-1825. 
Đorđević D. and Vesić Pavlović, T. (2020). Metadiskursni markeri u kontekstu sažetaka naučnih radova iz poljoprivredne tehnike. In: V. Lopičić, B. Mišić (Eds.), Jezik, književnost, kontekst (303-317). Niš: Filozofski fakultet.

Figar, V. (2018). Conjuctive Adverbs as Elements of Metadiscourse in Research Articles in the Field of Psychology Written by Native and Non-Native Speakers of English. Folia linguistica et litteraria, 21, 7-40

Gea Valor, M. L. (2000). A Pragmatic Approach to Politeness and Modality in Book Review Articles. Valencia: Universitat de Valencia.

Herriman, J. (2014). Metadiscourse in English and Swedish Non-fiction Texts and their Translations. Nordic Journal of English Studies, 13 (1), 1-32.

Hyland, K. (1998). Persuasion and context: The pragmatics of academic metadiscourse. Journal of Pragmatics, 30 (4), 437-455.

Hyland, K. (2004). Disciplinary interactions: metadiscourse in L2 postgraduate writing. Journal of Second Language Writing, 13 (2), 133-151.

Hyland, K. (2005). Metadiscourse: Exploring Interaction in Writing. London: Continuum.

Hyland, K. (2008). Persuasion, Interaction and the Construction of Knowledge: Representing Self and others in Research Writing. International Journal of English Studies, 8 (2), 1-23.

Hyland, K. (2009). Academic Discourse: English in a Global Context. London: Continuum.

Hyland, K. and Diani G. (2009). Introduction: Academic Evaluation and Review Genres. In: K. Hyland and G. Diani (Eds.), Academic Evaluation: Review Genres in University Settings (1-14). Basingstoke: Palgrave Macmillan UK.

Junqueira, L. and Cortes, V. (2014). Metadiscourse in book reviews in English and Brazilian Portuguese: A corpus-based analysis. Rhetoric, Professional Communication, and Globalization, 6, 88-109.

Kilgarriff, A. et al. SketchEngine (Computer Software and Information Resource). https://www.sketchengine.eu/.

Koprivica Lelićanin, M. (2014). Metadiskurs u savremenim italijanskim akademskim i novinskim člancima (unpublished doctoral dissertation). Beograd: Filološki fakultet.

Lee, J. J. and Casal, J. E. (2014). Metadiscourse in results and discussion chapters: A cross-linguistic analysis of English and Spanish thesis writers in engineering. System, 46 (1), 39-54.

Lin, C. (2005). Metadiscuourse in Academic Writing: An investigation of Graduate Students' MA Theses in Taiwan. Taiwan Journal of TESOL, 2 (1), 1-66.

Mauranen, A. (1993). Contrastive ESP rhetoric: Metatext in Finnish - English economics texts. English for Specific Purposes, 2 (1), 3-22. 
Motta-Roth, D. (1995). Book reviews and disciplinary discourses: Defining a genre. Unpublished manuscript, Letras Estrangerias Modernas, Universidade Federal de Santa Maria, Santa Maria, Brasil.

Motta-Roth, D. (1998). Discourse Analysis and Academic Book Reviews: A Study of Text and Disciplinary Cultures. In: I. Fortanet, S. Posteguillo, J. C. Palmer, J. F. Coll, (Eds.), Genre Studies in English for Academic Purposes (2 -85). Castello de la Plana: Universitat Jaume I.

Motta-Roth, D. (1996). Same Genre, Different Discipline: a Genre-Based Study of Book Reviews in Academe. The Especialist, 17/2, 99-131.

Piršl, D. (2009). Analiza retoričkih funkcija tekstualnog metadiskursa sportskog jezika. Sport Mont, VI $(18,19,20), 401-408$.

Šandová, J. K. (2008). Rhetorical Structure of English and Czech Academic Book Reviews. SKASE: Journal of Theoretical Linguistics, 15/3, 202-216.

Toumi, N. (2009). A Model for the Investigation of Reflexive Metadiscourse in Research Articles. Language studies working papers, 1, 64-73.

Vande Kopple, W. J. (1985). Some Exploratory Discourse on Metadiscourse. College Composition and Communication, 36/1, 82-93.

Zhang, M. et al. (2017). A multidimensional analysis of metadiscourse markers across spoken registers. Journal of Pragmatics, 117, 106-118.

Zou, H. and Hyland, K. (2020). Managing evaluation: Criticism in two academic review genres. English for Specific Purposes, 60, 98-112.

\section{SOURCES ${ }^{1617}$}

American Journal of Sociology, 2015/2: ES1; 2015/3: ES2-ES20.

Comparative Literature Studies, 2017/3: ELit1-ELit5; 2017/4: ELit6-Elit12; 2018/1: Elit13-Elit18; 2018/2: Elit19-Elit20.

Ethnography, https://blogs.lse.ac.uk/lsereviewofbooks/?s=ethnography+:E E1-EE20.

Istorija 20. veka, 2017/1: SH1-SH4; 2017/2: SH5-SH10; 2018/1: SH11-SH13; 2018/2: SH14-SH20.

Journal of Contemporary History, 2018/2: EH1-EH4; 2018/4: EH5-EH20.

Language, 2016/4: ELing1-Eling2; 2017/2: ELing3-Eling7; 2017/3: ELing8ELing12; 2018/1:ELing13-Eling15; 2018/2: ELing16-ELing17; 2018/3: ELing18-ELing20.

16 The complete list of the sources is available on request.

17 Referencing data for the sources were sometimes provided differently for printed and online version. We used the data for the versions in print. 
Sociologija, 2014/1: SS19, SS20; 2014/4: ]SS1, SS2, SS3; 2015/2: SS4, SS5, SS6; 2015/4: SS7, SS8, SS9, SS10; 2016/1: SS11, SS12; 2016/3: SS13, SS14; 2016/4: SS15; 2017/1: SS16; 2018/3: SS17, SS18.

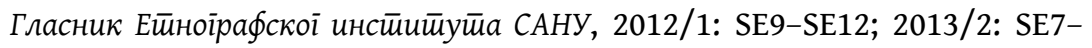
SE8; 2016/2: SE5-SE6; 2016/3: SE1-SE4.

Гласник Ейноїрафскої музеја, 2008: SE20; 2011: SE13-SE14; 2013: SE16-SE19; 2014: SE15.

3МСКJ, 2016/1: SLit1-SLit8; 2016/2: SLit9-SLit11; 2016/3: SLit12-SLit17; 2017/3: SLit18-SLit20.

ЗМСФЛ, 2015/1: SLing16-SLing19; 2015/2: SLing20; 2016/1: SLing13SLing15; 2016/2: SLing9-SLing12; 2017/1: SLing5-SLing8; 2017/2: SLing1SLing4.

АНА Љ. ВУЧИЋЕВИЋ

АЛЕКСАНДРА Д. РАКИЋ

УНИВЕРЗИТЕТ У КРАГУЈЕВЦУ

ФИЛОЛОШКО-УМЕТНИЧКИ ФАКУЛТЕТ

ЦЕНТАР ЗА ПРОУЧАВАҢЕ ЈЕЗИКА И КЬИЖЕВНОСТИ

РЕЗИМЕ

ТЕКСТУАЛНИ МЕТАДИСКУРС У АКАДЕМСКИМ ПРИКАЗИМА КЊИГА НА СРПСКОМ И ЕНГЛЕСКОМ ЈЕЗИКУ

Овај рад се ठави формама и обрасцима употребе маркера текстуалног метадискурса у академским приказима књига на српском и енглеском језику из области хуманистичких наука (лингвистике и књижевности) и друштвених наука (социологије, историје и етнографије). Основни циљ рада био је утврђивање потенцијалних разлика у употреби ових маркера у односу на параметре типа маркера, дисциплине и језика на којем су прикази написани. Квалитативно-квантитативна анализа спроведена је према моделу који је презентовала Благојевић (2008). Што се првог параметра тиче, поређење је показало да се, у односу на друге текстуалне конективе и маркере дискурсних радњи и упућивања на дискурс, у свим дисциплинама и на оба језика претежно јављају логички текстуални конективи. Када је реч о параметру дисциплине, прикази из дисциплина лингвистике, књижевности и социологије садрже највећи број маркера. У погледу критеријума језика, кад се све узме у обзир, више је текстуалних маркера уочено у приказима на српском језику него у приказима на енглеском. Међутим, разлика је незнатна, што указује на 
то да има више сличности него разлике у употреби маркера текстуалног метадискурса.

КљУчнЕ РЕчи: академски дискурс; академски прикази књига; текстуални метадискурс; дисциплине; српски језик; енглески језик.

Овај чланак је објављен и дистрибуира се под лиценцом Creative Commons Ауторство-Некомерцијално Међународна 4.0 (CC BY-NC 4.0 |

https://creativecommons.org/licenses/by-nc/4.0/).

This paper is published and distributed under the terms and conditions of the Creative Commons Attribution-NonCommercial International 4.0 licence (CC BY-NC 4.0 | https://creativecommons.org/licenses/by-nc/4.0/). 